\title{
PELAYANAN PERPUSTAKAAN DI DINAS PERPUSTAKAAN DAN KEARSIPAN KABUPATEN LOMBOK TIMUR
}

\section{LIBRARY SERVICE AT LIBRARY AND ARCHIVES SERVICE IN THE DISTRICT OF EAST LOMBOK}

\author{
Lulu Puji Istiana ${ }^{1}$, Amin Saleh ${ }^{2}$, Widiastuti Furbani ${ }^{3}$ \\ ${ }^{1,2,3,}$ Universitas Muhammadiyah Mataram \\ ${ }^{2}$ Email: cukup4min@gmail.com
}

\begin{abstract}
ABSTRAK/ ABSTRACT
Saat ini perpustakaan terus mengalami perkembangan dimulai dengan yang bersifat tradisional sampai saat ini masuk ke dalam era modern (digital). Perpustakaan dulu sistem pengelolaannya masih sangat sederhana, koleksinya pun sangat terbatas, pelayanan dan penyediaannya masih manual. Sedangkan perpustakaan saat ini sudah mengalami perkembangan dalam berbagai aspek seperti pengelolaan, koleksi, pelayanan, penyediaan, dan ilmu pengetahuan semakin berkembang. Oleh karena itu, pengembangan sumber daya manusia memerlukan proses inovasi dan kreatifitias yang berkelanjutan dan bertahap secara konsisten dan terencana dari semua pihak. Dinas perpustakaan dan kearsipan Kabupaten Lombok Timur hadir sebagai sarana penyedia informasi bagi seluruh masyarakat Kabupaten Lombok Timur. Diharapkan dengan adanya lembaga ini kualitas masyarakat Kabupaten Lombok Timur dapat lebih meningkat baik pengetahuan maupun keterampilan. Adapun metode yang digunakan untuk adalah dengan cara memperbaiki kulaitas pelayanan perpustakaan. Semua tahapan kegiatan pengabdian masyarakat di Dinas perpustakaan dan kearsipan Kabupaten Lombok Timur telah $100 \%$ dilaksanakan dan menghasilkan luaran diantaranya yaitu pelaksanaan pelayanan perpustakaan dan informasi kepada masyarakat dengan mengadakan berbagai kegiatan yang meningkatkan minat baca masyarakat.
\end{abstract}

Kata Kunci : Perpustakaan, pelayanan, pengabdian

Submited : 1 November 2021

Revision : 6 November 2021

Accepted : 10 November 2021

******

\section{A. PENDAHULUAN}

Perpustakaan adalah institusi pengelola koleksi karya tulis, karya cetak, dan/atau karya rekam secara profesional dengan sistem yang baku guna memenuhi kebutuhan pendidikan, penelitian, pelestarian, informasi, dan rekreasi para pemustaka (Undang-Undang RI Nomor 43 Tahun 2007 tentang perpustakaan). Perpustakaan umum adalah perpustakaan yang diperuntukkan bagi masyarakat luas sebagai sarana pembelajaran sepanjang hayat tanpa membedakan umur, jenis kelamin, suku, ras, agama, dan status sosial ekonomi (Lasa HS,2016:18). 
Saat ini perpustakaan terus mengalami perkembangan dimulai dengan yang bersifat tradisional sampai saat ini masuk ke dalam era modern (digital). Perpustakaan dulu sistem pengelolaannya masih sangat sederhana, koleksinya pun sangat terbatas, pelayanan dan penyediaannya masih manual. Sedangkan perpustakaan saat ini sudah mengalami perkembangan dalam berbagai aspek seperti pengelolaan, koleksi, pelayanan, penyediaan, dan ilmu pengetahuan semakin berkembang. Sehingga dengan adanya perkembangan tersebut, muncul istilah perpustakaan digital dimana pemustaka tidak perlu datang lagi ke perpustakaan untuk mencari informasi.

Dalam hal ini, perpustakaan secara tidak langsung mempunyai peranan yang besar dan ikut menentukan, terutama di negara-negara atau masyarakat yang perpustakaannya sudah maju. Perpustakaan merupakan salah satu barometer atas tingkat kemajuan dan kesejahteraan masyarakatnya. Namun ironisnya, bagi sebagian anggota masyarakat kita masih berkutat pada bagaimana meningkatkan minat dan budaya baca, bagaimana membina dan mengembangkan perpustakaan, dan bagaimana menyadarkan bahwa infromasi sangat penting bagi kehidupan (Suwarno, 2014, 34)

Tantangan dan kendala yang akan dihadapi dalam pengembangan perpustakaan semakin tinggi dalam persaingan di tingkat global, sehingga diperlukan kesiapan sumber daya manusia yang baik. Budaya baca sangat penting dalam menghadapi tantangan zaman pada masa kini dan masa depan untuk peningkatan daya saing bangsa. Oleh karena itu, pengembangan sumber daya manusia memerlukan proses inovasi dan kreatifitias yang berkelanjutan dan bertahap secara konsisten dan terencana dari semua pihak.

Perpustakaan daerah hadir untuk memberikan layanan secara prima kepada masyarakat agar dapat meningkatkan kegemaran membaca, serta memperluas wawasan dan pengetahuan untuk mencerdaskan kehidupan bangsa. Hal itu sejalan dengan Undang-Undang Nomor 43 Tahun 2007 tentang perpustakaan.

Dalam mengatasi tantangan ini, SDM yang diperlukan dalam ranah perpustakaan harus memiliki kemampuan yang kompeten. Seseorang yang memiliki kemampuan dalam bidang perpustakaan disebut pustakawan. Sehingga seseorang dapat dikatakan sebagai pustakawan apabila telah menempuh pendidikan formal atau 
telah mengikuti suatu pelatihan minimal 6 bulan. Hal ini mengacu pada tanggung jawab pustakawan yang dikatakan sebagai profesi dapat menjalankan secara profesional. Dengan didasari oleh ilmu pengetahuan yang luas dalam setiap disiplin ilmu sehinnga dapat di implemetasikan kepada pengguna perpustakaan agar dapat memenuhi kebutuhan informasi. Salah satu aspek perpustakaan dapat dinilai maju dilihat dari pustakawan yang terampil dan berawawasan. Pustakawan inilah yang dapat melakukan kegiatan pengadaan, pengelolaan, penyimpanan dan pelayanan di perpustakaan karena mereka yang memiliki ilmu pengetahuan tersebut.

Dinas perpustakaan dan kearsipan Kabupaten Lombok Timur hadir sebagai sarana penyedia informasi bagi seluruh masyarakat Kabupaten Lombok Timur. Diharapkan dengan adanya lembaga ini kualitas masyarakat Kabupaten Lombok Timur dapat lebih meningkat baik pengetahuan maupun keterampilan

\section{B. METODE}

Pelaksanaan kegiatan ini dilaksanakan di Dinas Perpustakaan dan Kearsipan Kabupaten Lombok Timur terletak di Jalan Dr. Cipto Mangunkusomo Nomor 5 Selong. Waktu pelaksanaan mulai tanggal 16 Maret 2021 hingga 30 April 2021 atau selama 45 hari. Metode yang digunakan dalam melakukan kegiatan ini dengan terjun langsung terlibat dalam kegiatan pelayanan di Dinas Perpustakaan dan Kearsipan Kabupaten Lombok Timur.

\section{HASIL DAN PEMBAHASAN}

Dinas Perpustakaan dan Kearsipan Kabupaten Lombok Timur memiliki berbagai saranan dan prasarana yang menunjang aktivitas penyedia informasi publik ke pada masyarakat. Dinas Perpustakaan dan Kearsipan Kabupaten Lombok Timur memiliki luas tanah $4.000 \mathrm{~m}^{2}$ dan luas gedung $1.056 \mathrm{~m}^{2}$. Gedung yang ditempati saat ini didesain untuk aktivitas perpustakaan yang menyangkut pelaynana untuk pemustaka. Untuk ruang koleksi bacaan, kapasitas ruangan dapat menampung lebih dari 20.000 eksemplar, ruang baca dapat menampung lebih dari 50 tempat duduk dan telah memenuhi unsur 5K. Kebersihan, Kerapihan, Kesegaran, Ketenangan dan Keamanan. 
Jumlah koleksi yang dimiliki oleh Dinas Perpustakaan dan Kearsipan Kabupaten Lombok Timur (tahun 2019) sejumlah 15.848 judul, 39.178 eksemplar dengan berbagai bentuk koleksi mulai dari buku, majalah, surat kabar, peta, APE, koleksi audio visual, referensi, dan koleksi muatan lokal. Jumlah anggota yang terdaftar sebanyak 2.58 orang pada tahun 2019, dimana setiap tahunnya anggota ini terus bertambah yang terdiri dari pelajar, mahasiswa dan masyarakat umum. Selama tahun 2019 total jumlah pengunjung adalah 85.679 orang. Jumlah pengunjung dan anggota perpustakaan tersebut di sesuaikan dnegan jumlah sumber daya manusia (SDM) yang ada di Dinas Perpustakaan dan Kearsipan Kabupaten Lombok Timur berjumlah 63 orang.

\section{Sistem Layanan}

Perpustakaan merupakan suatu unit yang memberikan layanan jasa pada para penggunanya. Pada umumnya sistem layanan di perpustakaan ada 3 yaitu sistem layanan terbuka, sistem layanan tertutup dan sistem layanan campuran. Dinas Perpustakaan dan Kearsipan Kabupaten Lombok Timur menggunakan sistem Layanan Campuran. Pada ruang koleksi umum pemustaka dapat dengan bebas mengambil bahan pustaka yang mereka butuhkan dan dapat meminjam koleksi tersebut. Sedangkan pada ruang referensi pemustaka tidak diperbolehkan dalam mengambil dan meminjam koleksi pada ruangan tersebut.

Jenis layanan yang terdapat pada Dinas Perpustakaan dan Kearsipan Kabupaten Lombok Timur antara lain:

a. Layanan baca di tempat

Layanan baca di tempat merupakan jenis layanan bagi pemustaka untuk membaca koleksi di ruang baca yang terletak di lantai 2. Pengunjung baik anggota maupun non anggota bisa membaca buku yang sudah disediakan.

b. Layanan keanggotaan

Layanan keanggotaan adalah layanan untuk menerima pemustaka menjadi anggota baru perpustakaan, untuk mendapatkan kartu baru perpustakaan. Masa berlaku kartu perpustakaan yang dimiliki oleh pemustaka adalah 1 tahun dan dapat diperpanjang masa berlakunya. 
c. Layanan sirkulasi

Layanan sirkulasi adalah layanan peminjamam, pengembalian, dan perpanjangan koleksi bagi pemustaka. Layanan sirkulasi di dinas perpustakaan dan kearsipan kabupaten lombok timur sudah berbasis automasi dengan aplikasi Inlislite.

d. Layanan referensi

Layanan referensi adalah layanan rujukan yang hanya boleh dibaca di tempat dan menjadi sumber rujukan bagi pemustaka maupun pustakawan untuk penelusuran informasi.

e. Layanan deposit dan muatan lokal

Layanan deposit dan muatan lokal merupakan layanan yang berisi semua koleksi lokal konten terkait dengan kabupaten lombok timur dan kabupaten lainnya di NTB, terbitan pemerintah, pengarang lokal, skripsi dan kliping koran atau surat kabar.

f. Layanan internet atau wifi gratis

Layanan internet atau wifi gratis merupakan layanan yang disediakan oleh dinas perpustakaan dan kearsipan kabupaten lombok timur yang bisa dimanfaatkan oleh pemustaka untuk mengakses informasi dari internet secara gratis dengan perangkat masing-masing pemustaka baik dengan laptop maupun smartphone.

g. Layanan multimedia

Layanan yang menyediakan pelayanan penggunaan komputer/PC yang terkoneksi internet secara gratis untuk pemustaka. Jumlah komputer/PC yang disediakan berjumlah 20 unit.

h. Layanan perpustakaan keliling

Layanan perpustakaan keliling merupakan salah satu layanan dinas perpustakaan dan kearsipan kabupaten lombok timur yang bertujuan untuk menjangkau pemustaka khususnya siswa-siswi sekolah atau pemustaka yang tinggal di daerah terpencil atau jauh dari lokasi perpustakaan. 
i. Layanan ruang baca anak

Ruangan ini selain menyediakan koleksi buku untuk anak, juga memiliki beberapa layanan, diantaranya, Story telling dan Layanan game edukatif dan APE(Alat Permainan Edukatif).

j. Layanan penelusuran informasi (OPAC)

Layanan katalog online merupakan pelayanan yang disediakan dinas perpustakaan dan kearsipan kabupaten lombok timur yang dapat membantu pemustaka dalam temu kembali informasi.

k. Layanan pinjam antar perpustakaan

Layanan pinjam antar perpustakaan merupakan layanan untuk peminjaman koleksi bahan pustaka antar perpustakaan.

1. Layanan bimbingan dan pendidikan pemustataka

Layanan pendidikan pemustaka merupakan pelayanan yang diberikan kepada pemustaka terkait dengan bagaimana proses pendaftaran anggota, peminjaman, pengembalian, pengenalan sarana prasarana perpustakaan atau teknis penelusuran informasi.

m. Layanan konsultasi

Layanan konsultasi merupakan layanan untuk melakukan konsultasi bagi pengelola berbagai jenis perpustakaan ataupun masyarakat yang membutuhkan informasi, teknis cara mengelola dan menyelenggarakan perpustakaan.

n. Layanan berbasis android (iLotim)

Layanan ini merupakan layanan perpustakaan digital yang disediakan oleh DPK lombok timur. Aplikasi iLotim ini berisi buku digital yang bisa dipinjam langsung dengan tenggnag waktu pinjam 3 hari, jika tenggang waktu pinjam sudah selesai maka secara otomatis akan kembali ke rak virtual.

o. Layanan inklusi sosial

Layanan inklusi sosoial bertujuan untuk menjadikan perpustakaan sebagai pusat kegiatan dan belajar untuk meningkatkan kesejahteraan masyarakat.

p. Layanan website (dpk.lomboktimurkab.go.id)

Pemustaka dapat mengakses berbagai kegiatan dinas perpustakaan kearsipan kabupaten lombok timur memlalui website termasuk OPAC, keanggotaan, dan Indonesia one search (IOS) 


\section{Pelayanan Perpustakaan}

Menurut Ase.S Muchyidin (dalam Isran, 2018) pelayanan merupakan kegiatan yang paling utama, di dalam perpustakaan yang di dalam pelaksanaannya dilakukan dengan melakukan hubungan baik secara langsung maupun tidak langsung di dalam pengguna (Isran, 2018). Adapun layanan perpustakaan yang dilakukan pada Dinas Perpustakaan dan Kearsipan Kabupaten Lombok Timur, yaitu:

\section{a. Shelving}

Di bidang pelayanan pada pukul 08:00 WITA kami melakukan kegiatan shelving. Shelving merupakan menyusun atau menata bahan pustaka pada setiap rak sesuai urutan nomor kelasnya, kegiatan rutin yang dilakukan setiap pagi. Kegiatan ini bertujuan untuk memastikan setiap koleksi berada pada rak yang sesuai dengan nomor kelasnya masing-masing dan untuk mengembalikan buku-buku yang telah dikembalikan oleh pemustaka untuk diletakkan kembali pada rak koleksi dan dapat dipergunakan lagi oleh pemustaka yang membutuhkan.

b. Layanan Sirkulasi
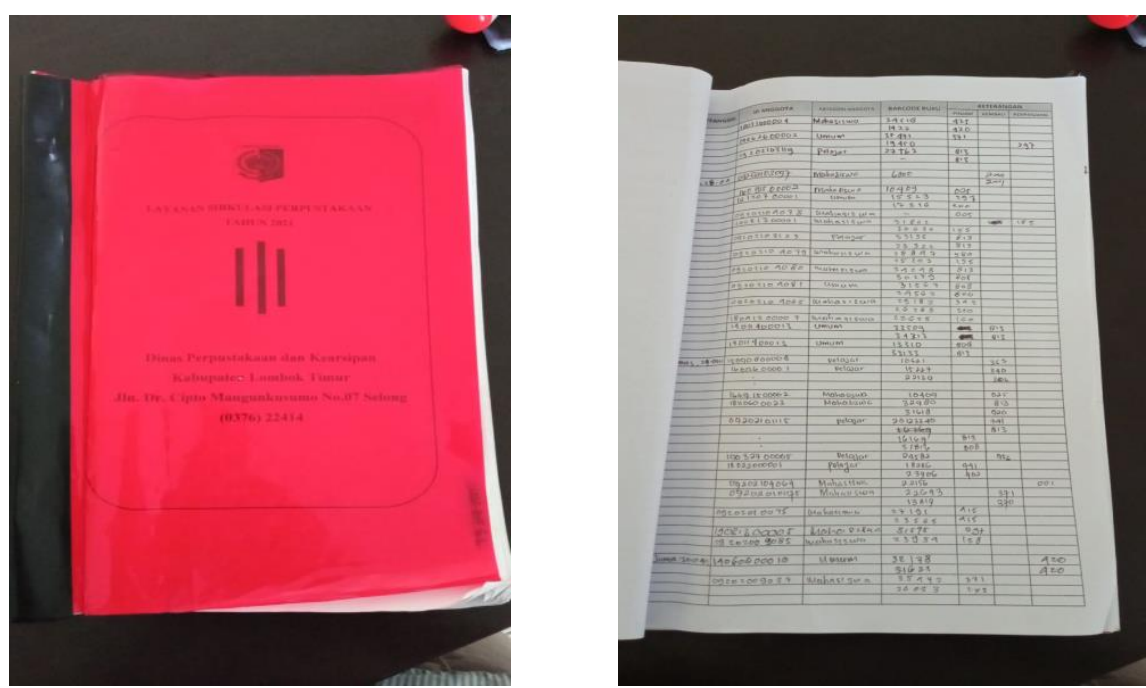

Kegiatan selanjutnya yaitu melakukan pelayanan sirkulasi, yaitu layanan peminjaman, pengembalian dan perpanjangan koleksi. Sistem layanan sirkulasi pada Dinas Perpustakaan dan Kearsipan Kabupaten Lombok Timur menggunakan dua cara yaitu menggunakan sistem Inlislite dan cara manual. Cara manual tersebut digunakan sebagai cadangan apabila sistem mengalami 
gangguan atau mati listrik. Sehingga apabila hal-hal tersebut terjadi pustakawan masih dapat memberikan pelayanan kepada pemustaka dengan cara manual.

c. Layanan Keanggotaan

Kegiatan pelayanan keanggotaan seperti pembuatan kartu anggota. Setiap pengunjung yang ingin mendaftarkan diri menjadi anggota harus melakukan pendaftraan terlebih dahulu. Syaratnya yaitu dengan menunjukkan kartu identitas dan mengisi data diri pada sistem yang telah disediakan dan melakukan pengambilan foto. Pada layanan keanggotaan memberikan pelayanan kepada pemustaka yang ingin memperpanjang masa kartu keanggotaannya dengan menyerahkan kartu anggota yang lama kemudian akan diganti dengan kartu anggota yang baru.

d. Layanan Perpustakaan Keliling
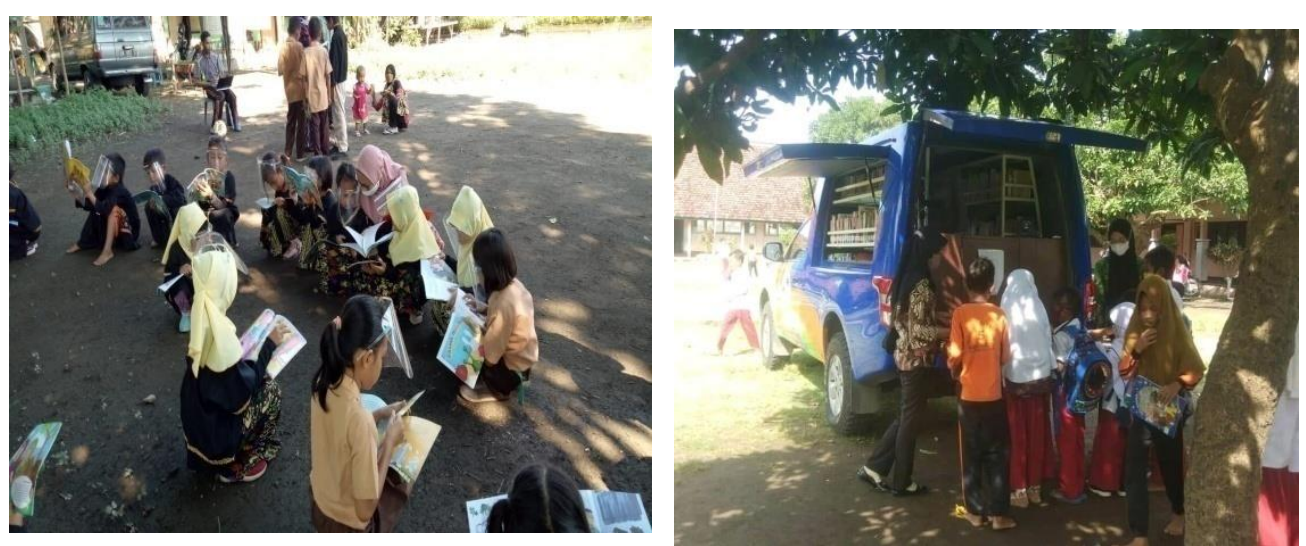

Sebagai perpustakaan umum Dinas Perpustakaan dan Kearsipan Kabupaten Lombok Timur tentunya harus dapat memberikan pelayanan kepada seluruh lapisan masyarakat dimanapun mereka berada. Oleh sebab itu layanan perpustakaan keliling ini bertujuan agar dapat melayani masyarakat yang terletak pada daerah pelosok. Kemudian setelah melakukan layanan petugas melakukan penginputan data ke sistem mengenai sekolah yang telah kami kunjungi lengkap dengan jumlah siswa/siswi yang mengikuti layanan tersebut. 
e. Layanan ruang anak
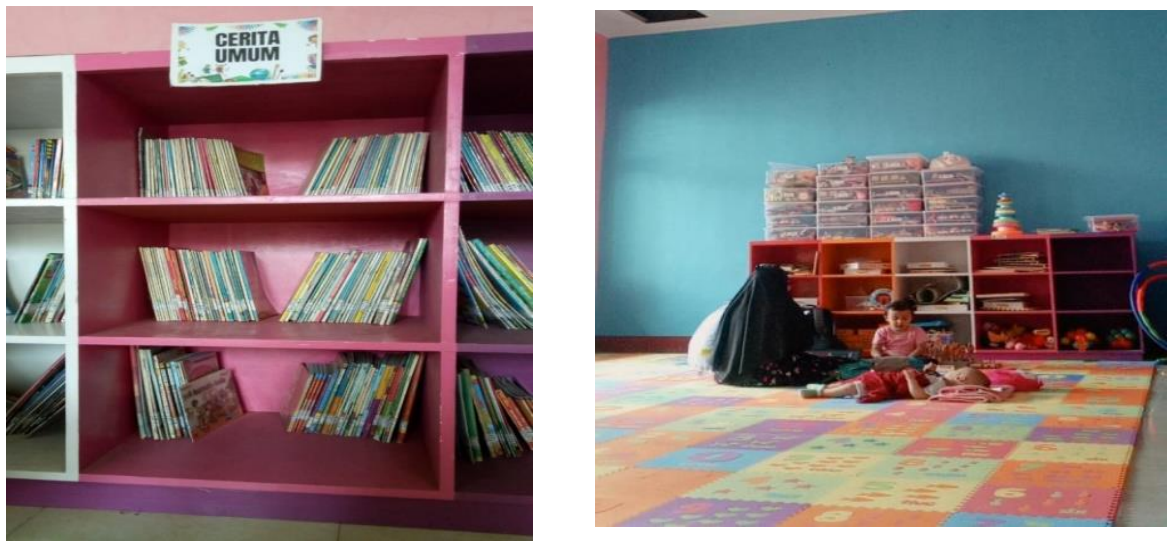

Pada layanan ruang anak berisi berbagai koleksi anak-anak dan alat permainan edukatif (APE). Pada layanan ruang anak kami melakukakan kegiatan shelving dan sirkulasi.

f. Pelestarian bahan pustaka

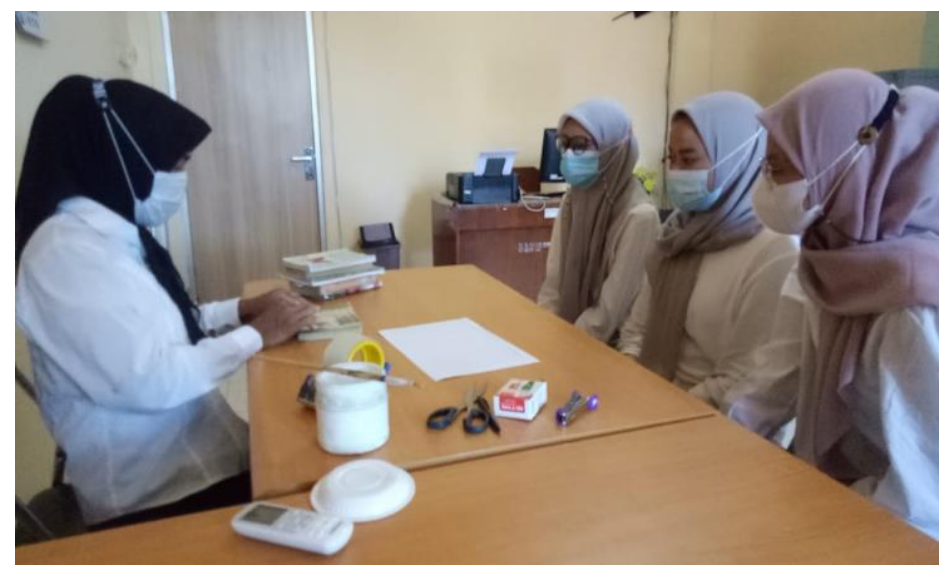

Kegiatan pelestarian bahan pustaka guna memperpanjang usia koleksi perpustakaan agar dapat dimanfaatkan oleh pemustaka. Koleksi akan tetap dapat dimanfaatkan oleh pengguna apabila dirawat dengan baik oleh pustakawan. Sehingga perawatan merupakan salah satu kegiatan yang sangat penting dilakukan untuk menjaga kelestarian koleksi perpustakaan.

Adapun kegiatan pelestarian/perawatan koleksi yang dilakukan di Dinas Perpustakaan dan Kearsipan Kabupaten Lombok Timur yaitu membersihkan debu-debu pada setiap rak buku dan ruangan koleksi menggunakan bulu ayam dan alat vacum agar kebersihannya lebih optimal. Kemudian pada setiap rak diberikan kapur barus agar terhindar dari hama dan serangga. Kemudian disemprotkan baygon untuk mengoptimalkan perlindungan pada koleksi. 
Kegitan fumigasi sendiri dilakukan pada beberapa bulan sekali jika ada libur panjang. Karena pada kegiatan fumigasi sendiri ruangan koleksi tidak boleh dimasuki oleh pengunjung selama seminggu akibat dari cairan kimia tersebut. Sehingga kegiatan tersebut cukup dilakukan dibeberapa bulan sekali.

Kegiatan lain yang kami lakukan dalam pelestarian bahan pustaka yaitu menyeleksi koleksi-koleksi yang mengalami kerusakan ringan ataupun berat pada ruang koleksi umum. Apabila koleksi mengalami kerusakan maka akan langsung diperbaiki, namun apabila koleksi mengalami kerusakan berat maka akan dilakukan penghapusan koleksi. Bahan-bahan yang diperlukan dalam memperbaiki koleksi yang rusak yaitu gunting, isolasi, lem rajawali, steples dan kuas. Koleksi yang telah diperbaiki kemudian didata. Hal-hal yang perlu didata meliputi nomor kelas, judul, pengarang, penerbit, jenis kerusakan, cetakan, tahun terbit dan jumlah eksamplar. Hal tersebut guna mengetahui koleksi-koleksi yang telah diperbaiki dan mengalami kerusakan berat sehingga tidak dapat dipergunakan lagi.

g. Layanan Referensi

Layanan referensi merupakan salah satu layanan yang ada pada Dinas Perpustakaan dan Kearsipan Kabupaten Lombok Timur. Jenis koleksi yang tersedia sangat beragam mulai dari agama, ensiklopedia, statistik, laporan, almanak, peta, atlas dan lain sebagainya. Koleksi-koleksi tersebut masih perlu didata menurut jenis, judul, eksemplar dan pengarang. Hal tersebut menjadi data mengenai koleksi referensi yang dimiliki Dinas Perpustakaan dan Kearsipan Kabupaten Lombok Timur. Pendataan tersebut menggunakan penulisan secara manual dan membuat file pada Microsoft excel.

h. Pengolahan bahan pustaka
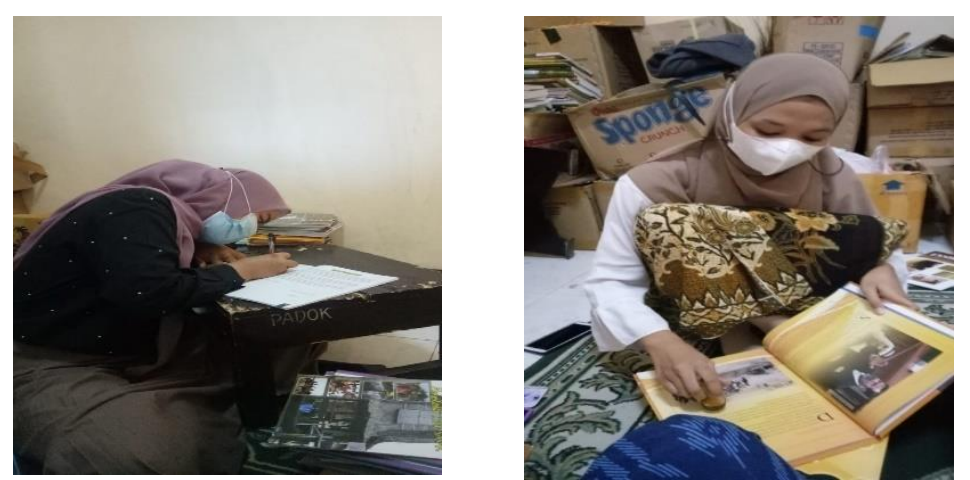
Pengolahan bahan pustaka merupakan kegiatan yang berkaitan erat dengan koleksi perpustakaan. Sejak koleksi tersebut tiba di perpustakaan sampai dapat dimanfaatkan oleh pemustaka. Adapaun proses pengolahan yang dilakukan adalah sebagai berikut:

i. Inventarisasi

Kegiatan inventarisasi meliputi kegiatan pemeriksaan bahan pustaka yang bertujuan untuk mengetahui jumlah dari suatu bahan pustaka yang telah dilakukan pengadaan dan memeriksa kelengkapan dari seluruh bahan pustaka. Karena ada beberapa bahan pustaka yang isinya tidak lengkap seperti bahan pustaka yang lain. Kemudian pemberian stempel pada setiap bahan pustaka, Kegiatan tersebut bertujuan untuk memberikan identitas bahwa koleksi tersebut merupakan milik Dinas Perpustakaan dan Kearsipan Kabupaten Lombok Timur. Pemberian stempel dilakukan pada 3 halaman.

Kegiatan inventarisasi ini dibuat dalam bentuk file excel agar lebih memudahkan dalam melakukan pencatatan bahan pustaka. Data-data yang dicantumkan pada inventaris ini meliputi nomor buku, nomor induk, judul, pengarang, penerbit, tahun terbit, edisi/cetakan, asal perolehan buku, harga, keterangan.

j. Klasifikasi

Kegiatan klasifikasi ini bertujuan untuk mengelompokkan buku sesuai dengan nomor kelas masing-masing koleksi. Sebelum melakukan klasifikasi bahan pustaka, pustakawan terlebih dahulu harus mengetahui subyek dari setiap bahan pustaka. Kegiatan klasifikasi pada Dinas Perpustakaan dan Kearsipan Kabupaten Lombok Timur menggunakan aplikasi e-class 2021 karya Rotmianto Mohamad yang diadopsi dari DDC (Dewey Decimal Classification). Sebagian besar buku-buku yang diolah adalah buku muatan lokal, karya umum, cerita nabi dan cerita rakyat. Penggunaan e-class ini cukup mudah, hanya perlu memasukkan subyek dari suatu koleksi maka akan muncul berbagai nomor kelas dengan subyek yang mirip dengan yang dicari. Setelah nomor kelas tersebut telah diketahui kita perlu menuliskannya pada pojok kanan atas atas buku lengkap dengan 3 huruf pertama nama pengarang, huruf pertama judul, eksemplar dan subyek. 
k. Survei penilaian responden

Sebagai pelengkap syarat reakreditasi, Dinas Perpustakaan dan Kearsipan melakukan survei kepuasan pemustaka. Survei tersebut berisi tentang pelayanan, koleksi, keadaan/suasana perpustakaan dan sarana prasarana. Selain menjadi bahan reakreditasi survei tersebut menjadi sebuah evaluasi bagi perpustakaan untuk dapat meningkatkan kualitas perpustakaan dari berbagai elemen. Survei tersebut dilakukan pada 25 Maret 2021.

1. Kegiatan Bergembira 2021

Bergembira merupakan salah satu program kerja dari bidang Layanan. Kegiatan ini di khususkan untuk peserta didik TK/PAUD/ RA DAN SD/MI yang ada di kabupaten Lombok Timur. Kegiatan yang ditampilkan dalam acara tersebut adalah senam, mendongeng dan pantonim. Kegiatan tersebut diikuti oleh 5 TK/PAUD. Acara ini berlangsung pada tanggal 8 April 2021.

m. Pembuatan poster layanan
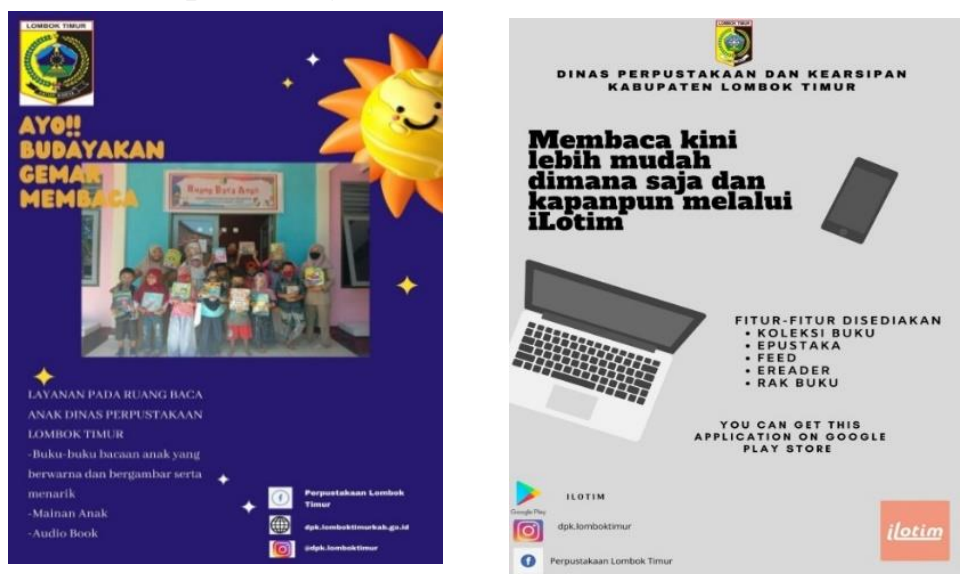

Poster merupakan salah satu media promosi yang sering digunakan. Layanan perpustakaan sangat penting untuk dipromosikan agar para pemustaka mengetahui mengenai layanan yang ada pada Dinas Perpustakaan dan Kearsipan Kabupaten Lombok Timur. Pembuatan poster juga dimuat sedemikian rupa agar dapat menarik minat pengunjung. Kegiatan pembuatan poster ini dibimbing langsung oleh salah satu pustakawan yang bernama Andrea Ardi Ananda, S.Hum. kami dibimbing dengan menggunakan salah satu software bernama canva. Masing-masing individu memilih ingin mempromosikan layanan. Setelah poster tersebut jadi, kami ditugaskan untuk mengunggah karya poster tersebut dalam akun sosial media masing-masing. Pembuatan poster tersebut berlangsung pada 14 April 2021. 
n. Membuat google formulir dan kuis menggunakan aplikasi Quizziz

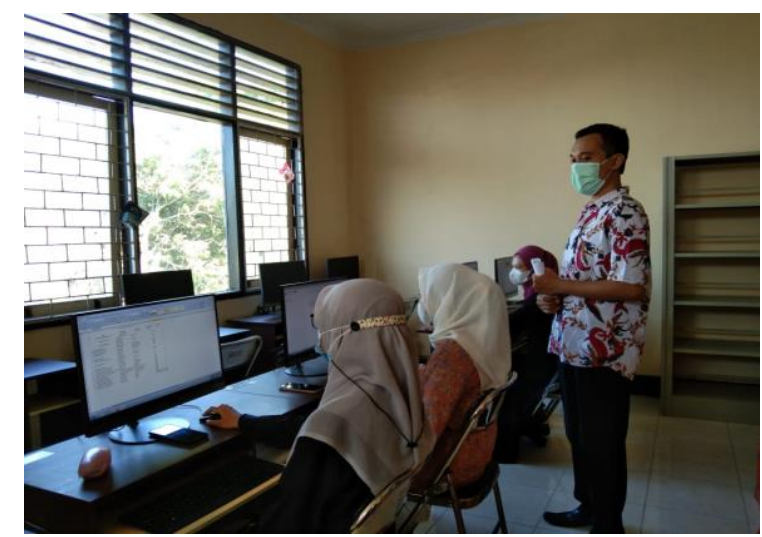

Selain melakukan kegiatan PKL, kami juga dibimbing dalam membuat media penyimpanan dan juga kuis menggunakan aplikasi Quizziz. Kegaiatan ini dibimbing oleh bapak Andrea Ardi Ananda, S.Hum. Selain itu ia menjelaskan kami fungsi dan proses pembuatannya dengan mendetail. Kamipun ditugaskan untuk membuat quizz masing-masing individu. Kegiatan ini berlangsung pada 30 April 2021.

\section{SIMPULAN}

Pelayanan Perpustakaan di Dinas Perpustakaan dan Kearsipan Kabupaten Lombok Timur sudah baik karena mampu memanfaatkan teknologi informasi yang dapat beriintegrasi dalam penyediaan informasi. Dinas Perpustakaan dan Kearsipan Kabupaten Lombok Timur menggunakan aplikasi Inlislite Versi 3.2, dengan adanya system aplikasi berbasis Integrated Library System ini dapat memudahkan pemustaka dalam temu kembali informasi dan pustakawan dalam mengolah bahan pustaka. Terutama adanya minat baca masyarakat sangat tinggi. Dilihat dari jumlah pengunjung dari berbagai kalangan yng sangat banyak dan dari kegiatan layanan perpustakaan keliling yang sangat diminati siswa-siswi sehingga perlunya peran pustskawan dalam menemukan informasi dan pendidikan pemakai dalam memanfaatkan secara maksimal perpustakaan. Dalam kegiatan pengadaan koleksi juga perlu memperhatikan kebutuhan informasi pemustaka sehingga kebutuhan informasi terpenuhi. Namun, terdapat beberapa kekurangan dalam hal penyediaan sarana ruang baca koleksi umum yang belum memadai sehingga diperlukan adanya pengembangan perpustakaan. 


\section{DAFTAR PUSTAKA}

Lasa HS. ((2008). Manajemen Perpustakaan. Jakarta: Gama Media.

Suwarno, Wiji. (2014). Ilmu Perpustakaan dan Kode Etik Pustakawan, Yogyakarta: ARRUZZ MEDIA

Undang-undang No. 43 Tahun 2007 Tentang Perpustakan. Jakarta: Perpustakaan Nasional RI. 2007. 